\title{
The Birth of Legal Radiological Sciences in Brazil
}

\author{
O Nascimento das Ciências Radiológicas Jurídicas no Brasil \\ El nacimiento de las ciencias radiológicas jurídicas en Brasil
}

Received: 01/22/2022 | Reviewed: 01/29/2022 | Accept: 02/04/2022 | Published: 02/06/2022

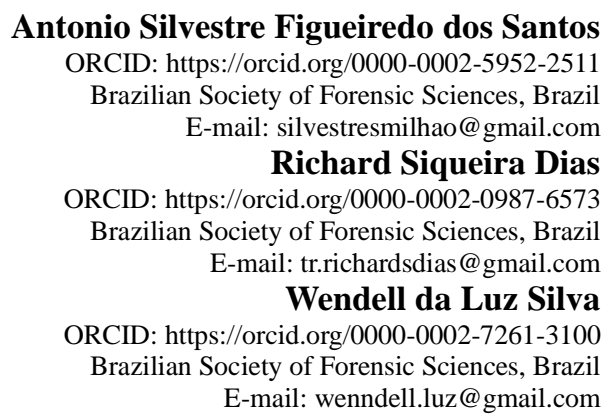

\begin{abstract}
The present work contemplates the objective of developing an exploratory study with a qualitative approach, aiming to include professionals of radiological techniques in state or federal public notices as specialists in Legal Radiology. Therefore, an exploratory literature review was carried out using the PubMed database. The reflections, so far, allow for the following inferences: a) the fields subject to expertise have their limits in the joint reading between Law No. 7394 / 85 and Resolution No. 2/2012 - CONTER; b) the absence of trained professionals in the area migrated the demands of specialists to related areas, given the application of different methodologies in the analysis of the same objects; c) the need to create a technical and standardized framework for the training and specialization of technicians and technologists in medical radiology in the field of Legal Radiological Sciences. However, the emergence of scientific works problematizing and systematizing expert attributions will open up new work opportunities and subbranches of expert activity in radiology.
\end{abstract}

Keywords: Legal radiological sciences; Legal sciences; Medical sciences; Forensic sciences.

\begin{abstract}
Resumo
O presente trabalho contempla o objetivo de desenvolver um estudo exploratório com abordagem qualitativa, visando incluir os profissionais das técnicas radiológicas em editais estaduais ou federais como especialistas em Radiologia Jurídica. Portanto, efetivou-se uma revisão de literatura exploratória através do banco de dados PubMed. As reflexões, até o momento, permitem as seguintes inferências: a) os ramos objeto de perícia têm seus limites na leitura conjunta entre a Lei $n^{\circ} 7.394$ / 85 e a Resolução n 2/2012 - CONTER; b) a ausência de profissionais capacitados na área migrou as demandas de especialistas para áreas afins, dada a aplicação de diferentes metodologias na análise dos mesmos objetos; c) a necessidade de criação de um quadro técnico e padronizado para a formação e especialização de técnicos e tecnólogos em radiologia médica no âmbito das Ciências Radiológicas Jurídicas. Contudo, o surgimento de trabalhos científicos problematizando e sistematizando as atribuições periciais abrirá novas oportunidades de trabalho e sub-ramos da atividade pericial em radiologia.
\end{abstract}

Palavras-chave: Ciências radiológicas jurídicas; Ciências jurídicas; Ciências médicas; Ciências forenses.

\section{Resumen}

El presente trabajo contempla el objetivo de desarrollar un estudio exploratorio con enfoque cualitativo, con el objetivo de incluir profesionales de técnicas radiológicas en avisos públicos estatales o federales como especialistas en Radiología Legal. Por lo tanto, se realizó una revisión exploratoria de la literatura utilizando la base de datos PubMed. Las reflexiones, hasta el momento, permiten las siguientes inferencias: a) los campos sujetos a especialización tienen sus límites en la lectura conjunta entre la Ley No. 7394/85 y la Resolución No. 2/2012 - CONTER; b) la ausencia de profesionales capacitados en el área migró las demandas de especialistas hacia áreas afines, dada la aplicación de diferentes metodologías en el análisis de los mismos objetos; c) la necesidad de crear un marco técnico y estandarizado para la formación y especialización de técnicos y tecnólogos en radiología médica en el campo de las Ciencias Radiológicas Jurídicas. Sin embargo, la aparición de trabajos científicos que problematizan y sistematizan las atribuciones de expertos abrirá nuevas oportunidades de trabajo y subramas de la actividad experta en radiología. Palabras clave: Ciencias jurídicas radiológicas; Ciencias jurídicas; Ciencias médicas; Ciencias forenses. 


\section{Introduction}

The birth of Forensic Radiology in the world follows the discovery of X-rays by a german physicist, Wilhelm Conrad Rontgen (1872) -1919), in 1895, who, after experiments with a vacuum tube, discovered (accidentally) that a paper containing platinum barium cyanide fluoresced when in contact with the rays coming from the ampoule. In 1896, a year after its discovery, a criminal case occurred in the USA in which the use of x-rays was essential. Radiological examination of the jaw of the victim killed by a firearm demonstrated the authorship of the murder, due to the presence of the lead projectile in the exposed structure (Bontrager \& Lampignano, 2015).

Before this event Brogdon (1998) report that the involvement of Forensic Radiology with Justice had a passage in Montreal, Canada, when 3 days before Röntgen's communication to the scientific society of Würzburg, “George Holder fired his gun over Tolson Cunning's leg. Several attempts were made to try to locate the projectile, but they all resulted in misfortunes. The wound healed, but Mr. Cumning persisted with the symptoms. At the request of the victim's physician, a professor of physics at McGill University, James Cox performed an X-ray of the injured extremity. In a Physics amphitheater all the material was made available, and at the end of 45 minutes of exposure the "photograph" showed a flat projectile "enclosed" between the tibia and the fibula. Tolson Cumning was then subjected to surgical intervention."

Since then, Forensic Radiology has been used as evidence and George Holder has been tried and sentenced to 14 years for attempted murder. The discovery of $\mathrm{x}$-rays was a watershed for modern medicine, avoiding unnecessary mutilations (Marie Curie and her daughter Irène Joliot-Curie were also the first to perform mobile x-rays in war camps, they collaborated to prevent mutilations). The numerous accidents and deaths surrounding irresponsible exposures were useful for advancing research on the effects of radiation interaction with matter (Loaiza et al., 2013). Even with all the progress, at first, the exams represented manifestations of the supernatural (Oliveira, 2014).

Several intellectuals, from the most varied branches of human knowledge, were interested in the discoveries, among them Dr. Fovau D'Courmelles, then director of the American X Ray Journal, who said: "the knowledge of the existence of a fracture in a person who was burned or mutilated beyond possible recognition, allows us with X-Rays to discover its identity". In the courts, most of the magistrates, responding to a kind of collective skepticism, were against the exams with the following arguments: "It is as if we were offered an image of a ghost" (Brogdon, 1998; Vale, 2009; Alves et al., 2015).

In Brazil, the first researchers to perform the radiology exam are not known for sure, as chronologically both were already working together. For this reason, it is almost impossible to precisely determine the first scientist to inaugurate the method on the ground national, although the reports are varied, ranging from Professor Alfredo Brito in Bahia, passing through Professor Silvia Ramos in São Paulo and Professor Francisco Pereira Neves in Rio de Janeiro (Carvalho, 1965; Croce \& Júnior, 2017; França, 2017).

It appears that the first radiology device in Brazil dates from the end of the 19th century, imported by the physician Carlos Pereira Pires. In this period, the greatest difficulty consisted in the lack of electrical energy. and medical technologies to improve the analysis and quality of exams. In the early days of radiology, in 1897, as a result of the Canudos War (November 1896 - October 1897), the Bahian doctor and professor Alfredo Brito performed radiological examinations on the battlefield, locating firearm projectiles in the wounded, during which approximately 98 radiographs and radioscopy were performed. (Oliveira, 2014; Alves et al., 2015; Furtado et al., 2018).

It is essential to highlight that the 19th century cosmovision in relation to radiology, even if contemporaneity considers it as a science (with its own methods and objects), at that time its application in Criminal Sciences was not consolidated. The evolution of Forensic Radiology in Brazil was not only accompanied by the technological and scientific development of medicine, but, above all, of Legal Medicine (Croce \& Júnior, 2017; França, 2017; Furtado et al., 2018).

The first work on legal medicine in the country, attributed to Gonçalves Gomide by Oscar Freire and Flamínio 
Fávero, dating from 1814, stands out in the eyes. 1832. In Bahia, the medico-legal school was founded, contemplating as main scholars Raimundo Nina Rodrigues (1894-1906), Estácio de Lima (professor in 1965) and Oscar Freire de Carvalho (professor from 1914 to 1923). Likewise, in Rio de Janeiro, with the distinguished professors Ferreira de Abreu, Afrânio Peixoto and Tenner de Abreu. Therefore, the development of Criminal Sciences follows the development of criminal means of execution, a phenomenon by which it is correct to explain the institutionalization and officialization of criminal expertise in Brazil (Carvalho, 1965; Brasil, 1998).

Above all, in the 20th century, Brazilian radiology underwent a turnaround with the arrival of several Brazilian doctors and scientists from Europe, with new research, methods and equipment. The height of this development occurs with the discovery of the abreugraphy method, developed by physician Manuel Dias de Abreu (1849-1962), who received the Nobel Prize in Physiology/Medicine (1946), to detect tuberculosis victims by means of X-rays chest. In the late 1940s, the first initiatives to institutionalize and bureaucratize the activity of professionals in radiological techniques appeared, in order to better meet governmental specifications regarding the use of radiation in human beings and provide ample training to these professionals. The first course created for this purpose was in São Paulo, at Hospital das Clínicas, in March 1951. During the course, the government enacted the first legislation in the area, Law no. 1,234/50 (Oliveira, 2014).

Only 55 years later, on October 29, 1985, Law 7,394/85 was enacted, originating from Bill 317/1975 by Deputy Gomes de Amaral and with enormous contributions from Mr. Jair Pereira, then president of the Association of the Radiology Technicians of the State of Goiás (ATREGO) and vice-president of the Federation of Associations of Radiology Technicians of Brazil (FATREB) (Furtado et al., 2018).

According to Ordinance SVS/MS n 453 formulated on June 1, 1998 and published in the official journal, the technical regulation that establishes the Basic Guidelines for Radiological Protection in Medical and Dental Radiodiagnosis, which provides for the use of diagnostic x-rays nationwide. In 2019, with the need for improvements in radiological protection, following the evolution of technology and replacing Ordinance SVS/MS No. According to RDC No. 330, the establishment of sanitary requirements and regulation of the control of medical, occupational and public exposures is carried out.

According to the Institute of Energy and Nuclear Research (IPEN) and the National Nuclear Energy Commission (CNEN), ethylenedicysteine diethyl ester dihydrochloride has applicability in imaging techniques using X-rays, which aim to determine pathologies. The pharmaceutical compound developed through Ethylene Cysteine Diethylester Dihydrochloride (ECD-TEC) is defined as suitable for the analysis of brain diseases, which include significant blood loss, chronic conditions including epilepsy, Alzheimer's and Parkinson's disease, even allowing the determination of brain death. This technique also helps when the disease is confirmed, and is used as a social security report. Specific substance is also used in Cerebral Perfusion Scintigraphy. On the other hand, the Gama Probe is a method of nuclear medicine to perform radioguided surgeries where it goes beyond the walls of clinics and hospitals with the methodology of using radioguided radioactivity. 
Figure 1. Representation of the detection of Alzheimer's disease through the imaging test corresponding to nuclear medicine.

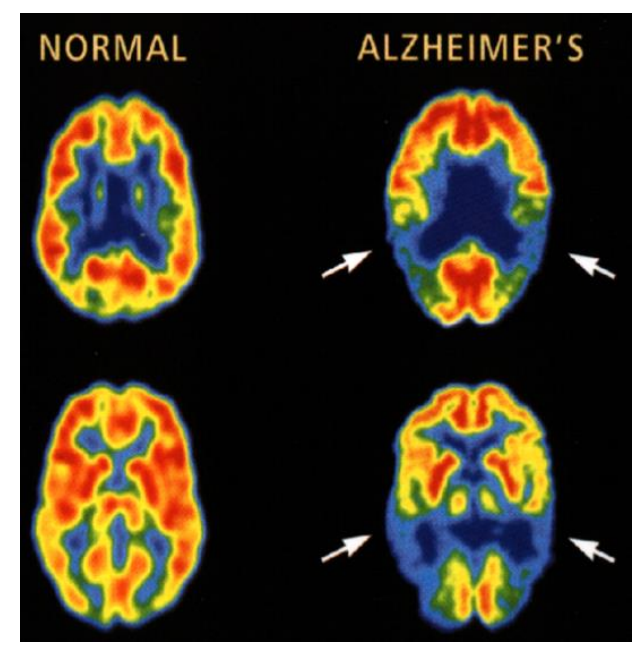

Source: Sironi (2015).

Figure 2. Displays the identification of brain death in nuclear medicine, legitimizing organ donation.
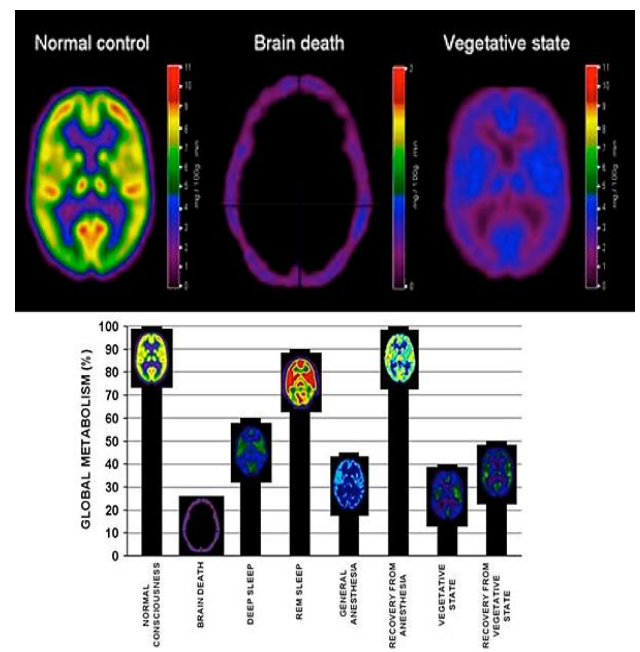

Source: Laureys (2005).

Figure 3. It presents an image obtained from the Gama Probe in radioguided nuclear medicine surgery.

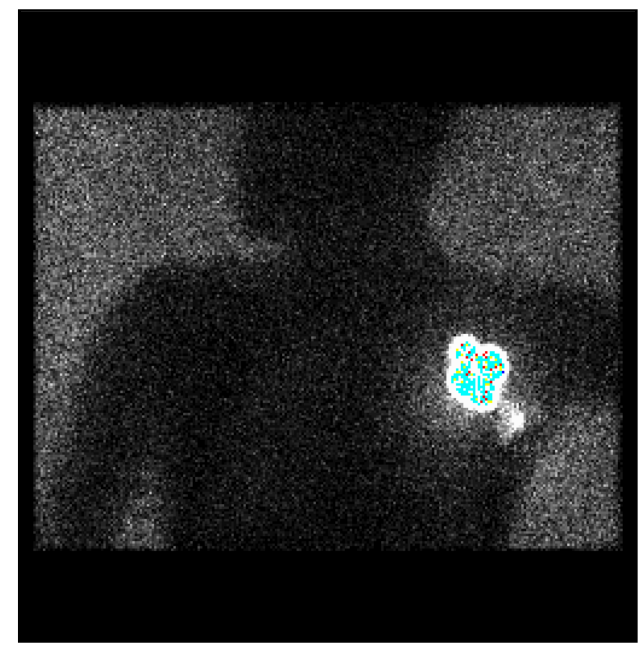

Source: Sironi (2015). 
The present study seeks to contribute to the construction of parameters to centralize and present in a unified way the methods of using forensic radiology/science of Legal Radiology for legal purposes for the benefit of the whole society, improving the resources of radiological technology in use of Legal Radiology. In this way, to include professionals of radiological techniques in state and federal public notices as specialists in Legal Radiology. These bodies (IMLs) already use this methodology in criminal body examinations (proving the presence of injuries in case of aggression, as well as their absence, also called forensic examination). The cadaveric report composes the radiological exams in the protocol and, therefore, justifies the team of specialists of radiology professionals to be included in the public notices of state or federal competitions for the application of their expertise.

\section{Methodology}

In order to achieve the proposed object, it was decided to develop an exploratory study with a qualitative approach based on the precepts of Legal Radiology®® and/or legal radiological sciences of the main thinkers in the field of activity of the object, as well as in the literatures of areas that also demonstrate depth and commitment to the exposed theme. Taking the benefit of this set of information to be used in legal cases and strengthening the birth of Radiologia Legal@ in Brazil within its operations.

Thus, an integrative literature review was performed, based on databases such as PubMed. Therefore, there were a total of 15 articles intermediated by selection criteria that covered materials in Portuguese or English from descriptors such as Radiology and Nuclear Medicine. According to Mendes (2008), this type of study described enables the comprehensive evaluation of research through rigorous criteria.

\section{Results and Discussion}

For Pin (2017), the Gama Probe is a manual instrument that basically consists of a cadmium telluride crystal with a small aperture collimator connected to appropriate electronic systems. The gamma-probe is based on a semiconductor that detects gamma photons by converting their interaction to a numerical signal and a sound signal recorded on a scale meter.

Figure 4. Shows the Portable Gamma detector.

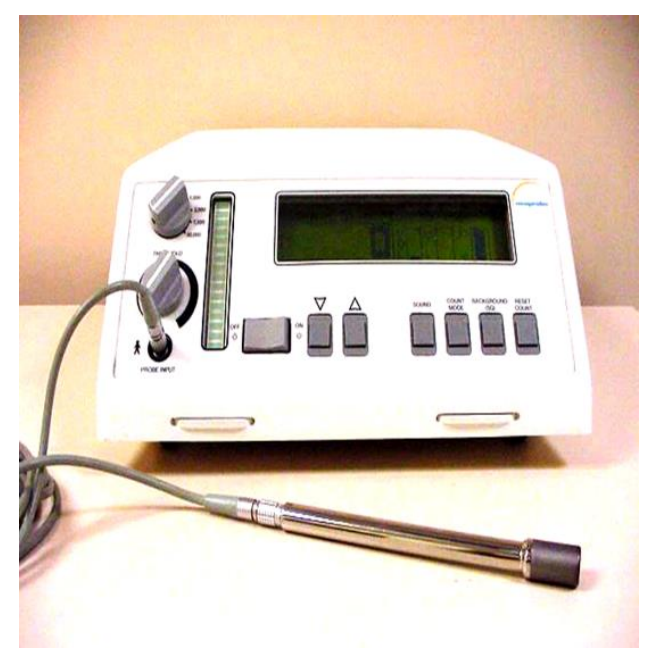

Source: Togni (2019).

The principles of operation detect the presence of gamma radiation, distinguish differences in the amount of gamma radiation emitted from different areas of the body or an organ, and translate the gamma energy pulses received by the detection 
probe into audible and numerical signals. Administration is performed by the nuclear physician in the sentinel lymph node (Pin, 2017; Gezer et al., 2020).

Figure 5. Shows the Gamma Probe performing the radioactive count of the surgically removed lymph node.

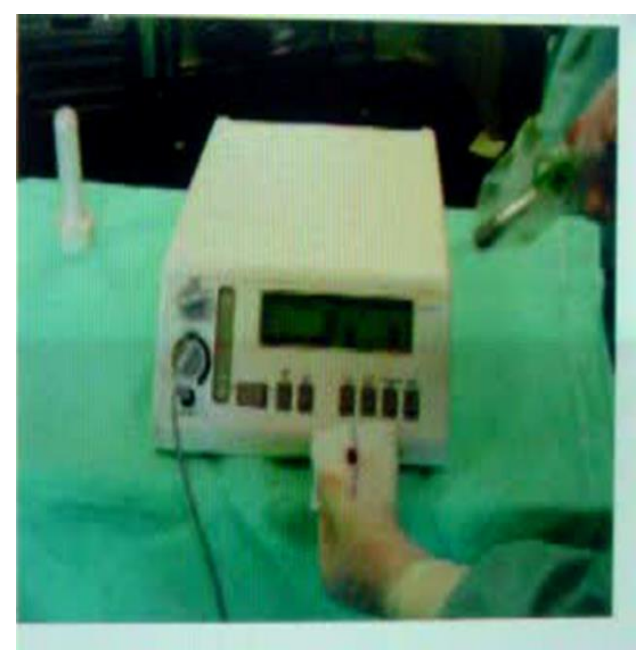

Source: Togni (2019).

Figure 6. Represents the administration of radiopharmaceuticals for radioguided detection in the operating room.

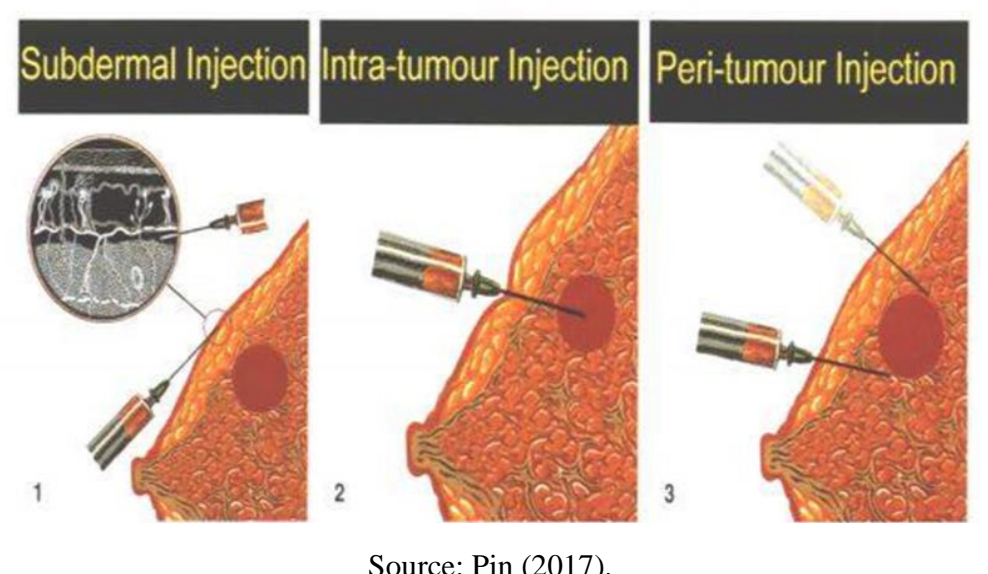


Research, Society and Development, v. 11, n. 2, e59811226050, 2022

(CC BY 4.0) | ISSN 2525-3409 | DOI: http://dx.doi.org/10.33448/rsd-v11i2.26050

Figure 7. Displays the delivery of the radiopharmaceutical to the patient's lymph node.

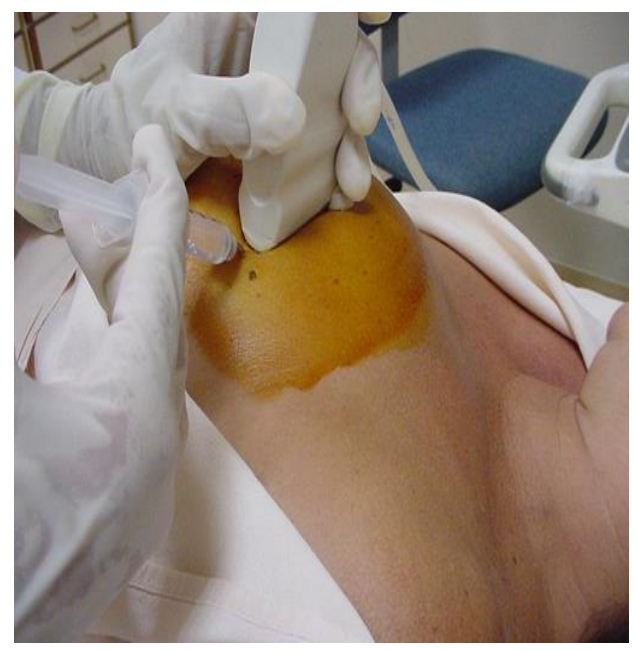

Source: Togni (2019).

Figure 8. Shows the radiopharmaceutical-labeled lymph node.

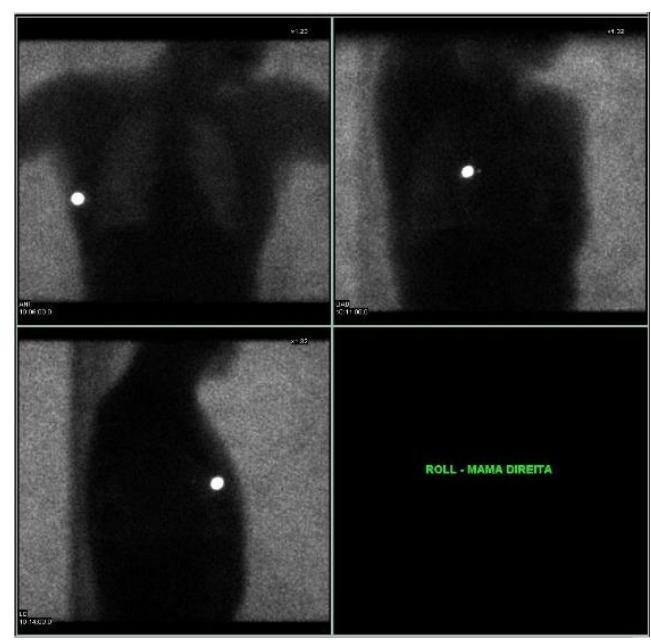

Source: Pin (2017).

Intraoperative gamma detection in the operating room includes counting over the skin tag (10s), detector in sterile surgical glove, after incision, SL survey and 10s counting over the SL. After excision of the SL, surgical bed count and specimen count should be performed (Togni, 2019). 
Figure 9. Shows the administration of the radiopharmaceutical to mark the sentinel lymph node in the breast.

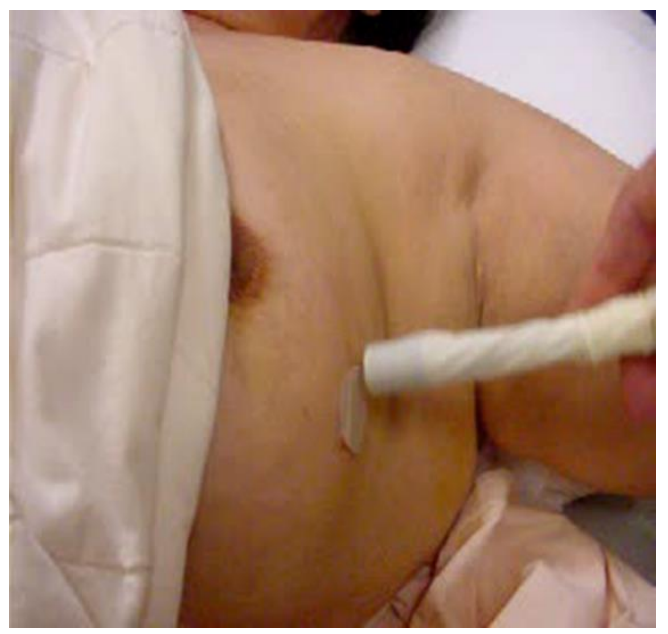

Source: Togni (2019)

Figure 10. It exposes the sentinel lymph node being surgically removed and confirmed with a Gamma Probe detector.

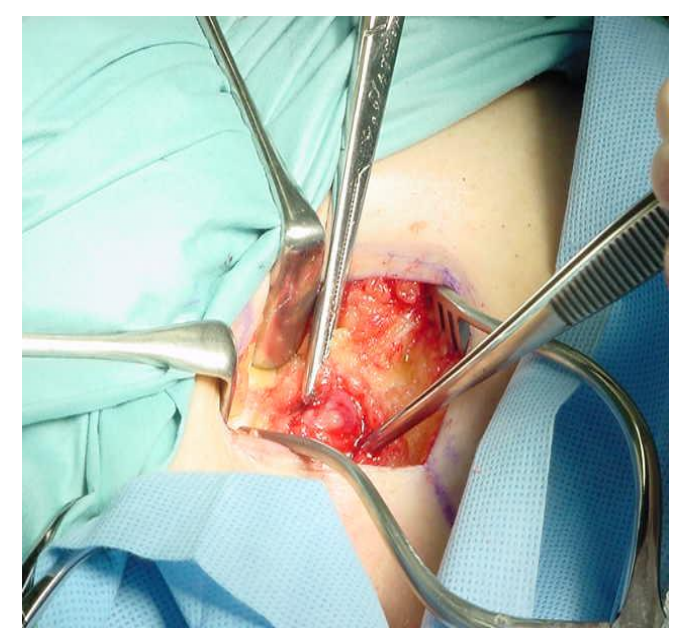

Source: Togni (2019).

Figure 11. Displays the Gamma Probe, confirming the high radioactive activity located in the sentinel lymph node of the patient's breast.

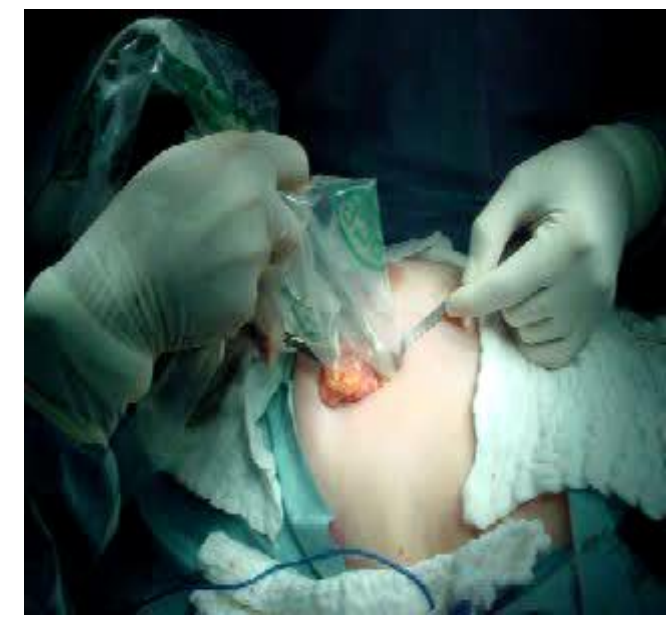

Source: Togni (2019). 
Legal Radiological Sciences can be subdivided into two theoretical branches of professional and scientific activity: Legal Radiology and Forensic Radiology. The first is defined as the scientific branch arising from Medical Radiology and Dental Radiology, Veterinary Radiology, Industrial Radiology, which is willing to establish new knowledge regarding understandings, legitimations, overlaps and applications, concerning issues arising from the legal, social, economic and cultural. Forensic Radiology, on the other hand, is established as a methodological technique of investigation, responsible for applying the results of radiological scientific phenomena to legal questions. Both Forensic Radiology and Legal Radiology use Virtopsy investigative techniques and their derivations as scientific-legal production methods (Santos et al., 2021; Sangonuga et al., 2022).

Flowchart 1. Displays the branches of Legal Radiological Sciences.

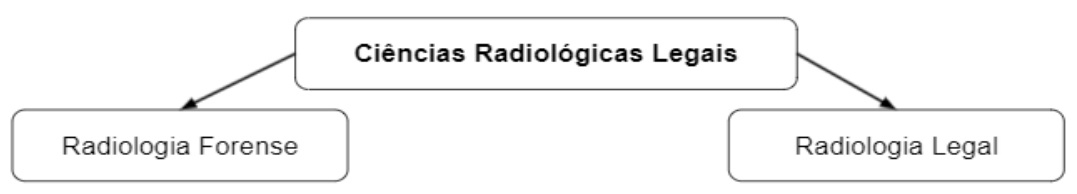

Source: Own authorship (2022).

\subsection{Virtopsy}

The term used as Virtopsy® is a hybrid word that unites two terms, whether "virtual" and "autopsy". Developed by Richard Dirnhofer, former director of the Institute of Forensic Medicine in Bern (Switzerland) and by Michael J. Thali, current professor and president of the Institute of Forensic Medicine at the University of Zurich (Switzerland), the term Virtopsy® is the combination derived autopsy, autos (own, yours) and opsomei (seeing with one's eyes), thus autopsy means seeing with one's own eyes (Thali et al., 2003). The term Virtopsy®, by itself, demonstrates the attempt to subtract the subjectivities of the exams, by the operator and the dynamization and opening of the possibility of new analyzes at any time (Malhotra et al., 2020).

Like the autopsy, Virtopsy® is a multidisciplinary approach that combines forensic medicine, pathology, biomechanics and digitized radiographic images of human organs and tissues to provide clues for forensic examinations (no photoshop), identification of cause and manner of death (Thali et al., 2007; Bezhenar et al., 2020).

According to Santos et al. (2021), Virtopsy ${ }^{\circledR}$ is an investigative tool with the purpose of determining the causes and circumstances of death, with the use of Forensic Radiology in the use of imaging in the three-dimensional reconstruction of the corpse. Virtopsy® does not replace the autopsy in all cases, but it is a great ally for different cases, offering non-invasive methods with faster completion and guiding if there is a real need for an autopsy, necropsy or cadaveric examination. The forms of investigation are classified as internal and external. Among the forms of internal investigation, there are Post-mortem X-rays, Post-mortem Computed Tomography, Post-mortem Magnetic Resonance, Post-mortem Ultrasound, Post-mortem Scintigraphy. However, the forms of external investigation include Photogrammetry, Stereophotogrammetry, Surface Scanning, Minimally Invasive Autopsy, Guided by Computed Tomography and Guided by Ultrasonography.

\subsection{Virtobot}

The first multifunctional robotic system called Virtobot was introduced at the Institute of Forensic Medicinein Bern, Switzerland in 2007. The "Virtobot" technique is a multifunctional machine that combines all imaging modalities, especially surface photogrammetry. Capable of performing fully automated 3D surface scans using an optical surface scanner and biopsy 
needle for CT-guided tissue and fluid collection. Applications of this tool enable dynamism in post-mortem documentation and the determination of the course of events during the accident (forensic kinematics) or criminal offense, becoming the gold standard for documenting surface wounds (Thali et al., 2003).

Breitbeck et al., (2013) point out the procedures for using Virtobot, as corpses in an advanced state of decomposition or charred are excluded from the investigation. The body needs to be properly cleaned to avoid artifacts produced by foreign bodies, hair, blood or other substances on the body surface. Lesions must be closed to reproduce the original wound. As for the cadaver's feet, these should be placed towards the gantry and fixed, to avoid sweeping movements. For the skin or around wounds, reference targets are applied and marker plates coded with photogrammetric calculations are fixed to the sides of the table to facilitate data integration.

\subsection{Vitomobile Virtobot's}

It ismobile installation that is easy to move to areas of major mass disasters (Thali et al., 2003; Vale, 2009).

\subsection{Virdentopsy}

The Virdentopsy is a interaction, threeterm "virtual", "dental" and "autopsy". The expression is born in 2020, during the COVID-19 pandemic, allowing the processing and recording of dental data from mortal remains, transmitted remotely to Forensic Dentistry specialists in various locations around the world. Theprocess Virdentopsy uses radiographic images (periapical $\mathrm{x}$-rays, 2D and 3D cone beam computed tomography, panoramic), 2D/3D photography and recorded video of the area of interest, photogrammetry documentation, 3D scanning performed by intraoral scanner.initiative Virdentopsy's unifies the interests of Forensic Radiology and Legal Radiology ${ }^{\circledR}$ in the demands of dentistry, providing a great tool in the construction of evidence for the legal method (Santos et al., 2021).

For Nuzzolese (2021), the succession of events for Virdentopsy consists of:

1- All corpses must be analyzed considering all states of decomposition, putrefaction, skeletonization and/or carbonization;

2- The process must have the photogrammetry documentation and photograph from the beginning of the cadaver's positioning, for emission of the periapical radiograph, until the creation of the digital image;

3- The Periapical Image should preferably be performed using a mobile or portable digital dental radiology device, collecting all 14 (fourteen) radiographic views of an EPC - Complete Periapical Examination;

4- The Occlusal Image should preferably be performed with a mobile or portable dental radiography device, collecting 02 (two) radiographic views, one of the total maxilla and the other of the total mandible;

5- Panoramic Images and Cone Beam Computed Tomography should only be performed respecting the state of decomposition of the corpse, being the first steps in the decomposition process before putrefaction or in the state of skeletonization acceptable for this acquisition;

6- The Intraoral Scanner must capture the entire lower and upper dental arch, considering part of this capture, also, the palatal face, lingual face, buccal face and occlusal face;

7- 3D printing must be performed using Cone Beam Computed Tomography in 3D reconstruction and using the 3D Intraoral Scanner;

8- The entire process of capturing radiographic images must be evidenced together with a odontogram to identify present and/or absent anatomical structures, as well as possible dental treatments performed. 


\subsection{Forseti}

The Forensic Autopsy System for Electronic Court Instruments - FORSETI is a multiprofessional cooperation system between physicians and radiologists involved in physical and virtual autopsy, used as integration and dynamism in the production of reports. The platform has a triple function: the first involves establishing an increase in reliability through the association between the knowledge of physical autopsy and Virtopsy®, as well as the joining of data obtained by coroners, pathologists or forensic radiologists and access to this data by authorities police or the judiciary. The initiative divides the purposes of the autopsy with the use of computer data into four large groups, the first two being aimed at improving data collection and its management. However, the last two can be understood as comparative and dissemination mechanisms (Malhotra et al., 2020; Santos et al., 2021). According to Wang et al., (2021), the flow of use of integrated data includes that:

1- Coroners and radiologists determine their specific protocols for each case differently;

2- Conventional Autopsy and Virtopsy ${ }^{\circledR}$ must be performed simultaneously, following the four steps already mentioned;

3- A simple external examination of the cadaver is performed, as well as the acquisition of surface data for classification and description of wounds in both conventional and Virtopsy® autopsies;

4- At the same time, complementary imaging and anatomopathological exams are produced for integration and production of integrated final reports on the cause of death;

5- Finally, the Virtopsy® report, produced by the radiologist, is delivered to the coroner to finalize his conventional autopsy report.

The final reports are produced at the same time through a series of juxtapositions of physical and virtual data: from the virtual model over the physical model of the corpse; of the photographs of the wounds over the real ones; and, the illustrative model of the accident or crime scene. The dynamics of data access, although performed by a multidisciplinary team, has the TR (technician) and TNR (technologist) professional as an indispensable moment for image acquisition and system feeding, similar to the Picture Archiving and Communication System - PACS (Santos et al., 2021; Wang et al., 2021).

Legal Radiological Sciences are born at the exact moment when it modifies the conventional methods and knowledge of Medical Radiology, Dental Radiology, Veterinary Radiology and Industrial Radiology, in order to apply them in the resolution of legal-scientific demands. And the conduction of this knowledge, as well as the formation of new paradigms, takes place through Forensic Radiology as an investigative technique and Legal Radiology $®$ as a mechanism for legal application (Carvalho, 1965; Loaiza et al., 2003; França, 2017).

Thus, the Legal Radiological Sciences are embodied in the act of taking the knowledge of forensic radiological techniques to the judiciary, through the official expert, the court or by the technical assistant, a professional duly registered in their professional body and with the appropriate administrative qualification/specialty with the object of the expertise (Brasil, 2015).

Delimiting the field of expertise of the judicial expert in radiological techniques only in the scope of the ante-mortem or post-mortem means observing the expertise in only one of its aspects, rejecting the breadth of applications of radiological forensic techniques. Thus, Legal Radiological Sciences are not diagnostic radio, radiotherapy, radioisotope, industrial and nuclear medicine, but comparative and, therefore, scientific-investigative, being present in all areas of ionizing or non-ionizing radiation (Brogdon, 1998; Kempner, 2013; Campilongo, 2017; Santos et al., 2021).

The objects subject to expertise for professionals in radiological techniques are contained in the combined reading between Law No. attributions, competences and functions of radiology technologist professionals (Brasil, 1985).

A scientific object is understood as any act or fact by which a science focuses in order to understand it, whether it is a social, psychological, pathological, radiological, physical or chemical phenomenon. In addition, attention should be paid to the 
fact that other sciences that wish to use their knowledge to resolve issues arising from the judiciary need to have autonomous scientific bases, otherwise, the forensic suffix will be assigned as the name of a practice - act of taking knowledge methods of a particular scientific branch to the public or to the forum (judicial) - and not a theorization (Rosa, 1999; Pataro, 2000; Croce \& Júnior, 2017; Kuhn, 2021).

\section{Conclusion}

We emphasize the need to create more effective methodological tools to study and include the Expert in Legal Radiological Sciences in the common framework of auxiliary experts to the Legal and Forensic Sciences. Such tools concern the essential knowledge to specialize the technician and technologist in radiology in the forensic activity, whether legal or specific. The legal ones focus on the elements contained both in the Code of Civil Procedure and Criminal Procedure, as well as in the other legal diplomas that are complementary to the expert activity. The specific ones, on the other hand, comprise the objects of action of radiological techniques, contained in Resolution No. 2/2012 - CONTER.

The recognition in the courts of the radiology professional as a judicial expert is the door that opens to demonstrate skills, competences and scientific production that characterize a robust knowledge on the subject. Therefore, the role of the Expert in Legal Radiological Sciences is extremely important with regard to the valorization of radiology, in view of the emergence of new theoretical and conceptual methods in this field, which justifies the value of the present study.

In view of all the aforementioned technological advances, where radiology professionals are the most prepared, a look at the STF (Federal Supreme Court) is necessary, so the recognition also for the construction of social security reports of professionals who requested special time retirement from the profession.

Finally, what should be sought is the insertion of the Expert in Legal Radiological Sciences in the framework of official experts in public tenders, the creation of specialization courses and the solidification of new work demands, given that today there are already professionals, whether they are radiology technicians or technologists appointed as judicial experts by CNJ Resolution No. 233 of July 13, 2016. Therefore, only Law 7,394/85, in accordance Wirth the aformentioned specialties, is in full compliance with RDC $\mathrm{N}^{\circ} 330$.

\section{References}

Alves, B. M. C., Fortes, M. L., Fernandes, M., Almeida, L., \& Alves, R. F. N. C. (2015). Investigação Radiológica em Ciências Forenses: Proposta de Pósgraduação (Trabalho de conclusão de curso).

Instituto de Pesquisas Energéticas e Nucleares. ECD TEC. https://www.ipen.br/portal_por/conteudo/centro_de_radiofarmacia/bulas/BULA_ECD TEC_Profissional_da_saude.pdf.

Bezhenar, V. F., Ivanova, L. A., \& Belitchenko, N. V. (2020). Comparative evaluation of ultrasonic virtopsia and classical autopsy for antenatal fetal death. Arkhiv Patologii, 82 (3), 51-54.

Bontrager, K. L. \& Lampignano, J. (2015). Tratado de Técnica Radiológica e Anatomia Associada.

Brasil (1985). Lei n ${ }^{\circ}$ 7.394, de 29 de outubro de 1985.. From https://www.planalto.gov.br/ccivil_03/leis/17394.htm.

Brasil (2015). Lei $n^{\circ}$ 13.105, de 16 de março de 2015. Código de Processo Civil, 2015. From http://www.planalto.gov.br/ccivil_03/_Ato20152018/2015/Lei/L13105.htm.

Breitbeck, R., Ptacek, W., Ebert, L., Fürst, M., Kronreif, G., \& Thali, M. (2013). Virtobot-A robot system for optical 3D scanning in forensic medicine. Proceedings of the 4th International Conference on 3D Body Scanning Technologies, 19-20.

Brogdon, B. G. (1998). Forensic Radiology.

Campilongo, C. F. (2017). Política sistema jurídico e decisão judicial.

Kempner, D. B. (2013). A importância da prova pericial. Especialize On-line IPOG, 1 (5), 1-18.

Carvalho, H. V. (1965). Lições de Medicina Legal. 
Croce, D. \& Júnior, D. C. (2017). Manual de medicina legal.

Vale, S. (2009). Pequena história da radiografia. Contemporânea, 7 (3), 58-67.

França, G. V. (2017). Medicina Legal.

Furtado, G. D., Sobral, S. F. E., Silva, S. A., Quirino, L. Á. H., \& Sampaio, A. C. A. (2018). Radiologia forense e sua atuação: uma breve revisão. Environmental Smoke, 1 (2), 110-119.

Gezer, Ş., Öztürk, S. D., Hekimsoy, T., Vural, Ç., İşgören, S., Yücesoy, İ., \& Çorakçı, A. (2020). Cervical versus endometrial injection for sentinel lymph node detection in endometrial cancer: a randomized clinical trial. International Journal of Gynecologic Cancer, 30 (3), $325-331$.

Kuhn, T. (2021). The structure of scientific revolutions. (S.l.): Princeton University Press.

Laureys, S. (2005). Death, unconsciousness and the brain. Nature Reviews Neuroscience, 6 (11), 899-909.

Loaiza, G. A. M., Daza, A. F. O., \& Archila, G. A. (2003). Applications of conventional radiology in the medical forensic field. Rev. Colomb. Radiol, 4 (24), 3805-3817.

Malhotra, T., Bhateja, S., \& Arora, G. (2020). Virtopsy: an aid in forensic investigation. IP International Journal of Forensic Medicine and Toxicological Sciences, 4 (4), 95-98.

Mendes, K. D. S., Silveira, R. C. de C. P., \& Galvão, C. M. (2008). Revisão integrativa: método de pesquisa para a incorporação de evidências na saúde e na enfermagem. Texto \& Contexto-Enfermagem, 17, 758-764.

Nuzzolese, E. (2021). VIRDENTOPSY: Virtual Dental Autopsy and Remote Forensic Odontology Evaluation. Dentistry Journal, 9 (9), $1-7$.

Oliveira, J. (2014). Forensic Radiology - History, applications and the job market. Retrieved February 2, 2022, from http://conter.gov.br/site/noticia/profissaorX.

Pataro, O. (2000). Medicina legal e prática forense.

Pin, C. (2017). Gama probe: intervenções radioguiadas. Retrieved February 2, 2022, from https://institutodemedicinanuclear.com.br/gama-probe/.

Portaria $n^{\circ} 453$ (1998). Provides for the technical regulation that establishes the basic guidelines for radiological protection in medical and dental radiodiagnosis. Brasília- DF.

Resolução no 330 (2019, 20 dezembro).

Rosa, M. V. F. (1999). Perícia judicial: teoria e prática.

Sangonuga, K. S., Kekana, M., \& Eze, C. U. (2022). Forensic radiography services: The experiences of radiographers and forensic pathologists in Nigeria. Radiography.

Santos, A. S. F., Dias, R. S., \& Silva, W. (2021). Imaging protocols for the autopsy service in a time of pandemic emergency minimizing the contagion of SARS-CoV-2 expert government agents. Research, Society and Development, 10 (6), 1-13.

Sironi, V. A. (2015). Ciência \& História/ Memória e esquecimento: história da demência de Alzheimer. Retrieved February 2, 2022, from https://www.ilsussidiario.net/news/emmeciquadro/emmeciquadro-n-59/2015/12/30/scienzaestoria-la-memoria-e-l-oblio-storia-della-demenza-di alzheimer/664497/.

Thali, M. J., Jackowski, C., Oesterhelweg, L., Ross, S. G., \& Dirnhofer, R. (2007). VIRTOPSY-the Swiss virtual autopsy approach. Legal Medicine, 9 (2), 100-104.

Thali, M. J., Yen, K., Schweitzer, W., Vock, P., Boesch, C., Ozdoba, C., Doernhoefer, T. (2003). Virtopsy, a new imaging horizon in forensic pathology: virtual autopsy by postmortem multislice computed tomography (MSCT) and magnetic resonance imaging (MRI)-a feasibility study. Journal of forensic sciences, 48 (2), 386-403.

Wang, B., Asayama, Y., Boussejra, M. O., Shojo, H., Adachi, N., \& Fujishiro, I. (2021). FORSETI: a visual analysis environment for authoring autopsy reports in extended legal medicine mark-up language. The Visual Computer, 1-13. 